\title{
RELATION BETWEEN SERUM FERRITIN AND VISCERAL FAT MASS IN AIN SHAMS MEDICAL STUDENTS
}

\author{
Ehab K. Emam *, Yasmin G. El Gendy* and Doaa A. Ismail**
}

\begin{abstract}
:
* Paediatric Department, Faculty of Medicine, Ain Shams University, **Paediatrician at Galaa Military Hospital. Cairo, Egypt.

Corresponding author

Doaa Atef Ismail

Mobile: (+2) 01007031764

E.mail:

dr.doaaatef@hotmail.com

Received: $13 / 6 / 2021$

Accepted: 6/7/2021

Online ISSN: 2735-3540

Background: Adipocytes are not just storage organs for fat, they play a regulatory role in body homeostasis including iron metabolism. Concerns about the effect of visceral fat mass on serum ferritin has been raised as increase visceral fat mass accumulation may lead to sequestration of $\mathrm{Fe}$ within the reticuloendothelial system leading to decrease dietary Fe absorption from the intestine

Aim of the work: This study aims to detect relation between percentage of visceral fat mass and serum ferritin level in Sample of Ain Shams medical students.

Patients and Methods: this was a case-control study conducted on 150 medical students over 3 months they were divided into two subgroups: normal serum ferritin group and low serum ferritin group. All students were subjected to the detailed history and 24 hour dietary recall, anthropometric measurements, complete blood picture, measurement of serum ferritin $=$

Results: There were significantly negative association between visceral fat mass and serum ferritin also the serum ferritin showed significant positive correlations with BMI and waist hip ratio.

Conclusion: Higher visceral fat mass levels should be taken into account when assessing body Fe status and should probably be treated before providing dietary recommendations to correct low serum ferritin level.
\end{abstract}

Keywords: visceral fat mass, serum ferritin

\section{INTRODUCTION:}

Ferritin, an acute phase protein, is elevated in inflammatory conditions and its regulation is complex including number of factors such as: oxidative stress, inflammation, oncogenes, growth factors and other stimuli were implicated ${ }^{(1)}$.

Body fat distribution is now recognized as an important predictor and modifier of many of the adverse health consequences of obesity. Individuals with an upper body fat pattern, reflecting an excess of visceral fat, have significantly greater risk for diabetes, hypertension, hypertriglyceridemia, ischemic heart disease, non-insulin-dependent diabetes some cancers, and death from all causes $^{(2)}$.

There is an indication that iron functioning in the maintenance of body weight and composition, and the relationship between adiposity and serum ferritin show a positive association, as excess fat may promote fatty acid oxidation and lead to oxidative stress, which has been shown to contribute to ferritin induction ${ }^{(3)}$.

The bioavailability of Fe may be also linked to the chronic inflammation induced by increase total and visceral fat mass accumulation, as during fat deposition, reactivity of intracellular iron with lipids and 
increase lipid peroxidation occur causing sequestration of intracellular iron into the stores in order to reduce lipid peroxidation, leading to reduce functional iron and increase iron stores ${ }^{(4)}$.

\section{AIM OF THE WORK:}

This study aims to detect relation between percentage of visceral fat mass and serum ferritin level in Sample of Ain Shams medical students.

\section{PATIENTS AND METHODS:}

\section{Patients:}

This is a case-control study conducted on 150 [31 male and 119 female] with normal BMI. They were recruited from clinical nutrition department, Ain Shams University. Their ages ranged between 19 and 22 years with a mean age of $18 \pm 1.5$ years. We excluded from the study, Students with chronic disease as: DM, hypertension, liver disorders, blood disease as thalassemia or hemoglobinopathy, obvious inflammation represent by serum C-reactive protein level of $20 \mathrm{mg} / \mathrm{dl}$.

The included patients 150 Medical students (age between 19-25 year's old) with normal BMI (BMI between 18.5-24.9 $\mathrm{kg} / \mathrm{m} 2$ ) were divided according to their serum ferritin level into two subgroups: 75 students with low serum ferritin level randomly allocated in case group by simple random sampling. And 75 of students with normal serum ferritin level will be randomly allocated in control group by simple random sampling.

The Ethical and Research Committee of the Council of Children Department, Ain Shams University, Egypt, approved this study proposal. Full description of what was required in the study was discussed with the parents of the participants, and consent was obtained before the evaluation.

\section{Methods:}

This survey was a part of the Nutritional Assessment of Medical Students of Ain Shams University (NAMES/ASU) project. This project was designed in 2018 to evaluate the nutritional status of 1225 medical students.

Data of 150 randomly selected medical students included in this study will be collected, this data will include detailed History: Demographic data: name, age, sex, Detailed medical history, Dietetic history: 24 hrs. Food recall And All data will be analyzed using food composition table National Nutrition Institute (NNI).

Anthropometric measurements were performed using standardized equipment's, these measurements included weight (wt) in kilograms (kg), height (ht) in centimetre (cm), waist circumference (WC) in centimetre $(\mathrm{cm})$,), body mass index, bioelectrical impedance segmental analysis using in-body 770. BMI was calculated according the following equation: $\mathrm{BMI}=$ weight $(\mathrm{kg}) /$ height (m2).

A volume of $6 \mathrm{ml}$ peripheral blood was collected from all participants using standard venipuncture techniques in two tubes. Of which $2 \mathrm{ml}$ on EDTA was utilized for complete blood picture, and $4 \mathrm{ml}$ serum was utilized for iron profile samples were excluded after centrifugation

Serum ferritin was assessed by IMMULITE/ IMMULITE 1000 Ferritin analyser (Siemens, Los Angeles, California, USA). Reference value in children for serum ferritin is greater than $10 \mathrm{ng} / \mathrm{dl}$.

The collected data were revised, coded, tabulated, and introduced into a PC using statistical package for the social sciences (SPSS Inc., Chicago, Illinois, USA)

\section{Statistical Analysis:}

Using PASS11 program for sample size calculation and assuming proportion of students with high visceral fat among low 
serum ferritin group $=50 \%$ and lower by $20 \%$ among normal group (30\%), sample size of 75 students in each group can detect this difference with power $80 \%$ and $\alpha$-error 0.05 .

\section{RESULTS:}

The results of this work show of 150 medical student (119 female and 31 male) included in this study: BMI (Mean \pm SD
$22.24 \pm 1.94)$ with weight range $42.4-81.4$ and height range147-183. The waist to hip ratio show range of $0.73-0.95$

Visceral fat mass show (Mean \pm SD $8.25 \pm 3.45)$ and serum ferritin level ranging from 3.3 to 260.3

There was positive correlation between serum ferritin Waist hip ratio $\mathbf{P}$-value $>\mathbf{0 . 0 5}$ While there was a negative correlation between serum ferritin and BMI.

Table (1): Correlation of serum ferritin and anthropometric Measurements.

\begin{tabular}{|l|c|c|}
\hline \multirow{2}{*}{} & \multicolumn{2}{|c|}{ Serum ferritin } \\
\cline { 2 - 3 } & $\mathrm{R}$ & P-value \\
\hline Height $(\mathrm{m})$ & 0.048 & 0.208 \\
\hline Weight $(\mathrm{Kg})$ & 0.062 & 0.454 \\
\hline BMI $(\mathrm{kg} / \mathrm{m} 2)$ & $-0.557^{* * *}$ & 0.000 \\
\hline Waist hip ratio & $0.520^{* *}$ & 0.000 \\
\hline Visceral fat $(\%)$ & $-0.392^{* *}$ & 0.000 \\
\hline
\end{tabular}

There was a negative correlation between serum ferritin and visceral fat $(\mathrm{P}$-value $>\mathbf{0 . 0 5})$

Table (2): Correlation of serum ferritin and Visceral Fat.

\begin{tabular}{|l|c|c|}
\hline \multirow{2}{*}{} & \multicolumn{2}{|c|}{ Visceral fat (\%) } \\
\cline { 2 - 3 } & $\mathrm{R}$ & P-value \\
\hline Ferritin & $-0.392^{* *}$ & 0.000 \\
\hline
\end{tabular}

\section{DISCUSSION:}

Regulation of ferritin is complex, a number of factors such as oxidative stress; oncogenes, growth factors and inflammation were implicated $^{(5)}$. And as visceral fat can lead to increased secretion of inflammatory mediators that have been reported to be inversely associated with serum $\mathrm{Fe}$ levels ${ }^{(6)}$. So aiming of our study is to detect the relation between percentage of visceral fat mass and serum ferritin level.

Our study performed on 150 medical students (119 female and 31 male) ranging in age from 19 to 22 years and BMI within the normal range. There was a significantly higher visceral fat mass in female compared to that in male.

As the correlation data indicated, serum ferritin showed a significant negative association with BMI. Many studies showed that inflammation resulted in increased production of liver hepcidin, which interferes with iron absorption, and the authors of these studies suggested that this may explain the low serum ferritin level associated with a high $\mathrm{BMI}^{(7)}$. Also other studies demonstrated that BMI was a risk factor for reduced serum ferritin levels ${ }^{(8,}$ 9\&10)

The positive association of ferrtin with waist circumference, and waist-to-hip ratio observed in current study was in line with the fact that most of previous studies have reported the significant association between elevated ferritin levels and abdominal obesity ${ }^{(11 \& 12)}$. Since lower body fat is less metabolically active, and thus less involved in oxidative metabolic processes than upper fat mass ${ }^{(13)}$. It is possible that the opposite associations are mediated by inflammatory factors $^{(14)}$ also these findings suggest that fatty acid oxidation may be implicated in the association between regional fat distribution 
and circulating ferritin levels. During fat deposition lipid biosynthesis increases, this might lead to an increase in iron induced lipid oxidation as a result of reactivity of intracellular iron with lipids. There is a probability that ferritin is elevated to act as an iron cytoprotective agent. Thus, increased ferritin concentration may be an adaptive mechanism to reduce iron-induced oxidative stress, which could explain the positive correlation between ferritin and anthropometric indicators ${ }^{(16)}$.

In our study we observe negative association between serum ferritin and visceral fat mass, the negative association between serum ferritin and adiposity was first demonstrated in adolescents and thereafter several studies have confirmed this finding in different populations ${ }^{(17,18}$, 19\&20) in contrast to those several studies, other studies reported positive associations between adiposity and serum ferritin $(21,22 \& 23)$. However, the study populations in previous reports generally differed from ours in terms of age, sex and race, and these factors can influence not only iron status, but also body composition ${ }^{(24,22 \& 25)}$. For instance, in the study by Chambers et al (2006) and Iwasaki et al (2005), the subjects included postmenopausal women, and the mean age of the study participants was over 50 years (22\&23). Although the study by Yanoff et al (2007) included subjects within range of 18 to 30 years, the mean age of their cohort (38 years) was substantially higher than the average age of in our study.

\section{Conclusion:}

This study indicates that visceral fat mass levels should be taken into account when assessing serum ferritin level and should probably be treated before providing dietary recommendations to correct ID or IDA

\section{REFERENCES:}

1. Humphreys L, Pustacioglu C, Nemeth E, and Braunschweig C. (2012): Rethinking Iron Regulation and Assessment in Iron Deficiency, Anemia of Chronic Disease, and Obesity: Introducing Hepcidin. J Acad Nutr Diet; 10:125-159.

2. Ioannis $\mathrm{K}$, Harpal $\mathrm{S}$, Constantine $\mathrm{T}$, Grigorios K, and Martin O..(2018): Clinical Problems Caused by Obesity. Endotext [Internet]; 8:258-266.

3. Alam F, Memon A and Syeda S. (2015): Increased Body Mass Index may lead to Hyperferritinemia Irrespective of Body Iron Stores.Pak J Med Sci.;8:350-359.

4. Pedro T., Hester H. Vorster \& Salome H. (2013): The Relationship between Iron Status and Adiposity in Women from Developing Countries: A Review. Critical Reviews in Food Science and Nutrition J.;17:1255-1268.

5. Galarisa D,Barboutib A, and Pantopoulos K. (2019): Iron homeostasis and oxidative stress: An intimate relationship.BBA Molecular Cell Research;1866(12): 1185359.

6. Domínguez A , Francisco M, García V , Domínguez R , Domínguez R , Rosa M. Mateos and Sancho M. (2020): Iron Metabolism in Obesity and Metabolic Syndrom. Int. J. Mol. Sci.; 21: 5529-35.

7. Guglielmi V, D'Adamo M, Bellia A. (2015): Iron status in obesity: An independent association with metabolic parametersand effect of weight loss. Nutr Metab Cardiovasc Dis.; 25(6):541-7.

8. Meydani SN, Dao MC. (2013): Iron Biology, Immunology, Aging, and Obesity: Four Fields Connected by the Small Peptide Hormone Hepcidin. Adv Nutr.;4(6):602-17.

9. Memish ZA, El Bcheraoui C, Tuffaha M. (2014): Obesity and associated factors-Kingdom of Saudi Arabia, 2013. Prev Chronic Dis.; 11:174-180. 
10. Zheng S, Shi S, Ren X.(2016): Triglyceride glucose-waist circumference, a novel and effective predictor of diabetes in firstdegree relatives of type 2 diabetes patients: crosssectional and prospective cohort study. J Transl Med.; 14:260-267.

11. Asakura K, Sasaki S, Murakami K, Takahashi Y, Uenishi K, Yamakawa M, Nishiwaki Y, Kikuchi Y,Takebayashi T. (2009): Japan Dietetic Students' Study for Nutrition and Biomarkers Group. Iron intake does not significantly correlate with iron deficiency among young Japanese women: A cross-sectional study. Public Health Nutr .; 12(9):1373-83.

12. Sri S, Nunik P, Retno H, Bambang W. (2016): Underweight as a Risk Factor for Iron Depletion and Iron Deficient Erythropoiesis among Young Women in Rural Areas of East Java, Indonesia. Mal J Nutr ; 22(2):219-32.

13. Hongyu $\mathrm{Wu}$, Qibin Qi, Zhijie Yu, Liang Sun, Huaixing Li, Xu Lin .(2010): Opposite Associations of Trunk and Leg Fat Depots with Plasma Ferritin Levels in Middle-Aged and Older Chinese Men and Women .PLoS ONE ; 5( 10):1331-6.

14. Cartier A, Cote M, Lemieux I, Perusse L, Tremblay A. (2009): Sex differences in inflammatory markers: what is the contribution of visceral adiposity. Am J Clin Nutr; 89: 1307-1314.

15. Karl Karl JP, Lieberman HR, Cable SJ, Williams KW, Glickman EL, Young AJ, McClung JP. (2009): Poor iron status is not associated with overweight or overfat in non-obese pre-menopausal women. J Am Coll Nutr; 28(1):37-42.
16. Onabanjo O, and Balogun O. (2014): Anthropometric and Iron Status of Adolescents From Selected Secondary Schools in Ogun State, Nigeria .ICAN: Infant, Child, \& Adolescent Nutrition.; 6 (2): 109-118.

17. Eftekhari MH, Mozaffari-Khosrav $\mathrm{H}$, Shidfar F. (2009): The relationship between BMI and iron status in iron deficient adolescent Iranian girls. Publ Hlth Nutr; 12: 2377- 2381.

18. Sri S, Nunik P, Retno H, Bambang W. (2016): Underweight as a Risk Factor for Iron Depletion and Iron Deficient Erythropoiesis among Young Women in Rural Areas of East Java, Indonesia. Mal J Nutr ; 22(2):219-32.

19. Pinhas-Hamiel O, Newfield RS, Koren I, Agmon A, Lilos P. (2003): Greater prevalence of iron deficiency in overweight and obese children and adolescents. Int $\mathbf{J}$ Obes Relat Metab Disord; 27: 416-418.

20. Nead KG, Halterman JS, Kaczorowski JM, Auinger P, Weitzman M. (2004): Overweight children and adolescents: A risk group for iron deficiency. Pediatrics; 114: 104-108.

21. Iwasaki $T$, Nakajima $A$, Yoneda $M$, Yamada Y, Mukasa K, Fujita K, Fujisawa N, Wada K, Terauchi Y. (2005): Serum ferritin is associated with visceral fat area and subcutaneous fat area. Diabetes Care; 28(10):2486-91.

22. Yanoff LB, Menzie CM, Denkinger B, Sebring NG, McHugh T, Remaley AT, Yanovski JA. (2007). Inflammation and iron deficiency in the hypoferremia of obesity. Int J Obes; 31(9):141-148.

23. Chambers EC, Heshka S, Gallagher D, Wang J, Pi-Sunyer FX, Pierson RN.(2006): Serum iron and body fat distribution in a multiethnic cohort of adults living in new york city. J Am Diet Assoc; 106(5):680-4. 


\title{
Ehab K. Emam, et al.,
}

\author{
العلاقه بين تركيز الفيريتين فى الام ونسبه الدهون الحثويه

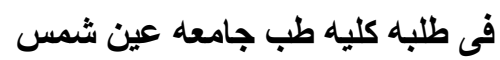

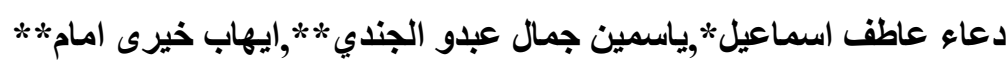 \\ * قسم الاطفال ، جامعة عين شمس** قعم الاطفال بمستشفى الجلاء للقو ات المسلحة
}

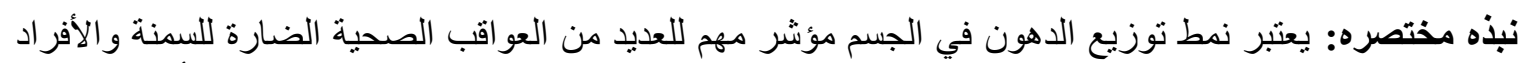

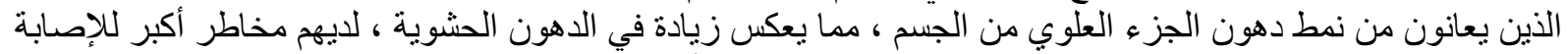

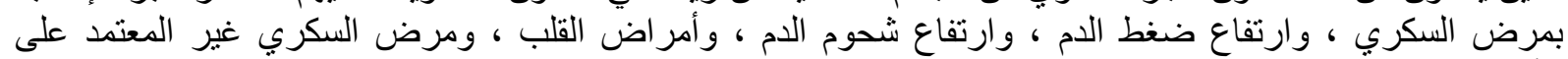

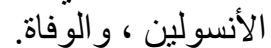

الهدف من البحث: تهدف هذه الدراسة الى الكثف عن العلاقة بين النسبة المئوية لكتلة الدهون الحشوية ومستوى الفيريتين في الدم في عينة من طلبة كلية البدة الطب عين شمس.

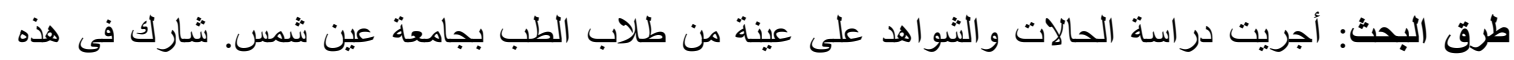

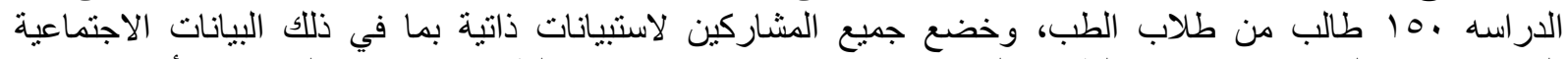

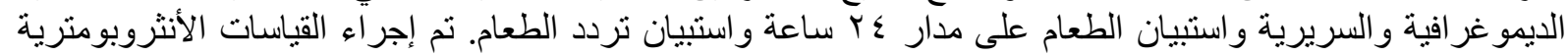

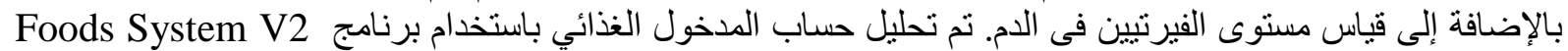
Nutri Plus ، و الذي يعتمد على تكوين الأطعمة.

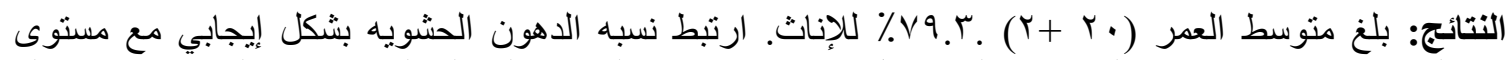

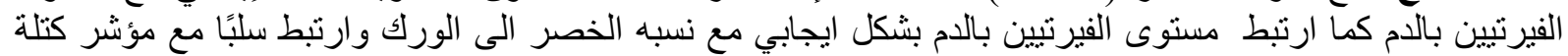

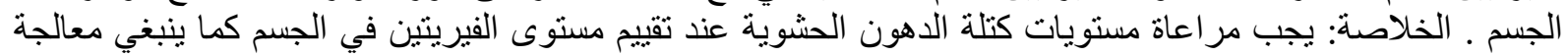
كتلة الدهون الحشوية قبل تقديم التوصيات الغذائية للمريض الذئ يعانى من نقص نسبه الحديد بالدم .

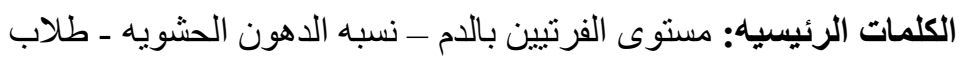

